\title{
Enhancing the Quality of Engineering Undergraduates through Effective Entrepreneurship Skills
}

\author{
Bankole Adebanji, Bamide Olusola Ogunlade, and Kayode James Adebayo
}

\section{ABSTRACT}

Published Online: August 08, 2021

ISSN: $2736-4534$

DOI :10.24018/ejedu.2021.2.4.141

\section{B. Adebanji*}

Electrical and Electronic Engineering, Ekiti State University, Nigeria.

(e-mail: bankole.adebanji@eksu.edu.ng) B. O. Ogunlade

Bamidele Olumilua University of Education, Science and Technology, Ikere-Ekiti, Nigeria.

(e-mail: ogunladebamidele1@gmail.com) K. J. Adebayo

Mathematical Sciences, Ekiti State University, Nigeria.

(e-mail: akj7070@yahoo.com)

*Corresponding Author

\section{INTRODUCTION}

Entrepreneurial skills can be described as the quality or ability to possess the right form of knowledge to perform and operate effectively as a successful entrepreneur [1]. The major aim of entrepreneurship education is to provide the required skills and knowledge needed for students to find an enabling environment for a new venture. Entrepreneurship can also be described as the ability to apply the laudable qualities of initiative thinking, creativity and risk-taking into the work environment using necessary apparatus for success in the environment [2]-[4]. It raises better standard of living, reduces crime rate and alleviating poverty level among the youths.

The rate of unemployment in Nigeria is increasing everyday with almost two million young graduates entering the labour markets every year. The rate of unemployment in the country rose from $13.9 \%$ in 2016 to $33.5 \%$ in the first quarter of 2020 [5]. This is indeed very worrisome. One of the major reasons for this is that most of them are not employable-they do not possess the right skill for them to be self-reliant in their chosen professions. They lack the required entrepreneurial skills to start and build businesses of their own.

The massive turn-out of graduates from our different institutions of higher learning is not in tandem with the available vacancies in the labour market. This lack of synergy between the turn-out of graduates and the available employment opportunities, up surged the alarming rate of graduate unemployment in Nigeria [6]. The lack of ability to secure gainful employment after graduation is not unconnected to the non-equilibrium between the highly skilled labour market requirements and lack of entrepreneurial skills expected for them to be excellent in their jobs. Unemployment is the major cause of so many social vices like armed robbery, kidnapping, banditry, and lack of security.

Honestly, most of the graduates from our tertiary institutions, lack the needed skills to make them employable in this highly-tech global labour market. Even those who are lucky to be employed often performed below the standard and display high level of incompetency. Quality entrepreneurial skill is the required tool to improve the productive power of employees. A highly-skilled and self-employed graduates performed excellently well in the modern tech-world. They are expected to possess the right saleable knowledge that is needed for excellent performance in their areas of discipline [7], [8].

Some of the identified causes of graduate unemployment are lack of national employment policy, sub-optimal quality of graduates, inappropriate educational curricula, inconsistent government policies, and educational system not 
tailored and aligned to the basic need of industries [6], [9].

The labour market has undergone gradual changes from "paper work" to what someone can really contribute in concrete terms to the society. Employers of labour are now in search for well-equipped entrepreneurs with relevant technical expertise [1], [2].

In order to curb this trend, the Federal Government of Nigeria (FGN) through the Federal and State Ministries of Education introduced some entrepreneurial courses into the entire tertiary institutions' curricula aimed at enhancing high level of productivity among undergraduates in the country. The main objective of the initiative is to equip the graduates with the needed knowledge in their areas of discipline coupled with appropriate skills to make them globally competitive and able to be employers of labour [9].

Graduate engineers are supposed to be employers of labour rather than job seekers. Interestingly, engineers are modeled to be creative and innovative. The young engineers need to be self-reliant, employers of labour and capable of setting up personal businesses after graduation. The relative importance of entrepreneurship skills to engineers cannot be over emphasized. He or She will contribute immensely to the growth of any country in social and economic terms [6], [11].

A successful entrepreneur must be able to possess effective practical, creative and interpersonal characteristics traits. Succinctly put, an effective integration of entrepreneurial training will respond promptly to the fast-changing economy [8]. Successful entrepreneurs necessarily have to take time to conduct research and develop a plan before kick-starting their projects. He/she must be able to "think out of the box" in order to generate the needed ideas for a product or service. "Thinking out of the box" requires doing what people would rarely do. Sometimes entrepreneurial ideas could come from unlikely places, from unlikely people and from unlikely situations or circumstances. A good entrepreneur immediately recognizes these ideas and seizes them in engineering pedagogy [9], [12].

Reference [6] stressed the need for both private and governments at all levels to come together in encouraging graduates to look at the agricultural sector for investment. Reference [9] opined a counter-active top-down approach to job-creation program design as one of the ways of reducing the unemployment rate. There is need for effective government policy linking the educational system and developing university curricula that go beyond theoretical knowledge [13]. There is also need for mentorship roles to be self-reliant by having role models in the society.

Conducive environment for learning entrepreneurial skills will eventually have a multiplier effect at producing highly skillful and quality graduates that are impactful. The basic needed ingredients for a sustaining environment are technology real advancement, infrastructures, and investments. Provision of incentives and opportunities for entrepreneurs can also be made available by well-meaning institutions for innovations and risk-taking. Successful entrepreneurs search for how to make changes, responds to the changes, exploits the opportunity to promote and accelerate the environment for successful entrepreneurship practice. However, the changes made to the environment can either be harmful or of benefits to the environment [14]-[16].

Stakeholders in educational management has not given much attention to the issues of entrepreneurial skills aimed at providing the required skills and knowledge in enabling students to be successful in starting businesses of their own in engineering methods of teaching. The advent of technology has brought fundamental changes to the traditional ways of doing things into the high-tech global working environment [17]. Surely, the workplace in the nearest future will be more dynamic and knowledge-driven than what we have today. Hence the need to prepare students to be able to adapt to this changed working environment. It is imperative to integrate entrepreneurship education into their entire education system. Some of the famous universities in the world (Standford, Harvard and MIT) have embraced entrepreneurship education in their curricula.

Some relevant authors have worked in this area [1], [2], [6], [9], [10]. Some of these authors reported that the introduction of these courses has brought positive impact on the students and also recommended for expansion of the programme to accommodate more students in their respective case study areas. However, very few papers have been able to give much attention to entrepreneurship education where it requires:

- new thinking in relation to the fast-changing techworld;

- quality entrepreneurial skills as panacea to graduate unemployable issues.

Entrepreneurship requires a poly-functional mind set. This paper discussed the issues of unemployment among gradu ates and the need to create an enabling environment for new start-ups. The study used a descriptive research design of survey type in assessing the impacts of entrepreneurship skills on Nigerian Engineering students.

\section{A. Problem Statement}

If not until recently, the issue of entrepreneurship education in engineering has not been given much attention [7], [8]. The increasing rate of unemployment among thousands of graduates from our different higher institutions posed a serious danger to the economic, security and social life of the citizenry in the nearest future. Most employers of labour argued that the graduates are not employable. They also lack the required entrepreneurial skills such as selfconfidence, independence, optimism, leadership skills, innovation, and creativity.

In order to curb this trend, the FGN, through the federal and the state ministries of education introduced some new entrepreneurial courses into the entire tertiary institution curricula aimed towards enhancing high level of productivity among undergraduates in the country. Hence, the necessity to appraise the impacts of these courses introduced few years ago into all tertiary institutions all over the country. The country seems absolutely unprepared for the global change that is presently moving from traditional way of doing things to more dynamic and knowledgeable intensive environment

\section{B. Research Questions}

These research questions guided the study.

- What entrepreneurial skills should be acquired at the Nigerian tertiary institutions to promote self-reliance in engineering? 
- What are the challenges facing the implementation of entrepreneurial skills in engineering program in Nigerian tertiary institutions?

\section{Hypothesis: A null Hypothesis Guided the Study}

$\mathrm{Ho}_{1}$ : There is no significant difference between the perception of private and public tertiary institution lecturers on the challenges facing the implementation of entrepreneurial skills in engineering program in Nigerian tertiary institutions.

\section{Methodology AND DESCRIPTION OF THE SAMPLE}

The study employed descriptive research design of survey type and was carried out in Ado-Ekiti, Nigeria. The population consisted of 205 lecturers in faculties of Engineering of two (public and private) universities and a polytechnic in Ado-Ekiti, Nigeria. Sample size of 132 engineering lecturers which represents $68 \%$ of the total population was selected using proportional random sampling technique from the institutions.

Research instrument entitled: Questionnaire on Impact of Entrepreneurial Skills on Engineering Students (QIESES) designed in a four point Likert-scale of (Strongly Agree-SA, Agree-A, Disagree-D, Strongly Disagree-SD) rated 4, 3, 2, and 1 respectively was used to collect the expected data. The instrument was validated through face, content validity and also ascertained by two experts in the faculty of engineering and educational technology in Ekiti State University, AdoEkiti, Nigeria. The corrections were affected in the final format of the instrument.

The modified instrument was tested and reliability index of 0.81 was established using Pearson product moment correlation coefficient. Data collected were analysed using appropriate descriptive and inferential statistics of frequency counts, mean, standard deviation (SD), and T-test. The mean of 26.0 was taken as the benchmark or mean criterion for taking decision such that a mean response that falls below 26.0 was not significant while a mean response on or above 26.0 was significant.

The hypothesis generated was tested at 0.05 level of significance in order to find the difference between the mean values of public and private Engineering lecturers on the entrepreneurial skills implementation in Nigerian institutions. Table I shows that $123(24.6 \%)$ of the respondents are from Ekiti State University, (EKSU), Ado-Ekiti Engineering students, 199 (39.8\%) are from Afe Babalola University, (ABUAD), Ado Ekiti and 178 (35.6) are from Federal
Polytechnic, (FEDPOLY), Ado- Ekiti, respectively.

Table II shows that $32(24.2 \%)$ of the respondents are between 10-14 years of teaching, $60(45.5 \%)$ are between 15 19 years of teaching while $40(30.3 \%)$ are between 20 and above years of teaching.

\section{DATA ANALYSIS OF RESULTS}

Research question 1: What entrepreneurial skills should be acquired at the Nigerian Tertiary institutions to promote self- reliance in engineering?

In questionnaire item 1 in this table, a total number of 400 respondents strongly agreed that Motivation arouse the interest of the learners while 10 respondents strongly disagreed that Motivation arouse the interest of the learner representing mean of 34.0. This indicates that entrepreneurial education draws the attention of engineering students and motivates them. Also, in questionnaire item no 2, a total number of 350 respondents strongly disagreed that achievement of intention makes the job goal difficult and the mean is 14.0 .

Furthermore, in questionnaire item 3, 400 respondents strongly agreed that self-confidence helps to achieve the objective of the entrepreneurial lesson, whereas a total number of 30 respondents strongly disagreed. The mean is 32.0. This implies that self-confidence skills can help to achieve the objective of the entrepreneurial lesson if properly considered as an entrepreneur skill while handling job in engineering. In questionnaire item no 4, 350 respondents, strongly disagreed that resourcefulness makes the lesson difficult to understand while 20 respondents strongly agreed that resourcefulness makes the lesson difficult to understand, and the mean is 18.0 .

\begin{tabular}{ccc}
\multicolumn{3}{c}{ TABLE I: DISTRIBUTION OF THE ENGINEERING STUDENTS BY LEVEL } \\
\hline Class level & Frequency & Percentage \\
\hline $\begin{array}{c}\text { EKSU engineering students } \\
\text { (500 Level) }\end{array}$ & 123 & 24.6 \\
ABUAD engineering Students & 199 & 39.8 \\
(500 level) & 178 & 35.6 \\
FEDPOLY (HND II) & 500 & 100.0 \\
Total & & \\
& & \\
TABLE II: DISTRIBUTION OF THE LECTURERS BY EXPERIENCE \\
\hline Age & Frequency & Percentage \\
\hline 10-14 years & 32 & 24.2 \\
15-19years & 60 & 35.5 \\
20years and above & 40 & 100.3 \\
Total & 132 & \\
\hline
\end{tabular}

TABLE III: EXPECTED ENTREPRENEURIAL SKILLS IN NIGERIAN TERTIARY INSTITUTION

\begin{tabular}{|c|c|c|c|c|c|c|c|}
\hline $\mathrm{S} / \mathrm{N}$ & Items & SA & $\mathrm{A}$ & $\mathrm{D}$ & SD & Mean & Remark \\
\hline 1 & Motivation arouses the interest of the engineering & 400 & $\begin{array}{c}80 \\
160\end{array}$ & 10 & 10 & 34.0 & Accepted \\
\hline 2 & $\begin{array}{c}\text { Achievement of intention makes the job goal } \\
\text { difficult. }\end{array}$ & $\begin{array}{l}30 \\
6 \%\end{array}$ & $\begin{array}{l}20 \\
4 \%\end{array}$ & $20 \%$ & $\begin{array}{l}350 \\
75 \%\end{array}$ & 14.0 & Rejected \\
\hline 3 & $\begin{array}{l}\text { Self-confidence helps to achieve the objective of } \\
\text { the entrepreneurial lesson }\end{array}$ & $\begin{array}{l}400 \\
80 \%\end{array}$ & $\begin{array}{c}50 \\
10 \%\end{array}$ & $\begin{array}{l}20 \\
4 \%\end{array}$ & $\begin{array}{l}30 \\
6 \%\end{array}$ & 32.0 & Accepted \\
\hline 4 & $\begin{array}{c}\text { Resourcefulness makes the lesson difficult to } \\
\text { understand }\end{array}$ & $\begin{array}{l}20 \\
4 \%\end{array}$ & $\begin{array}{l}30 \\
6 \%\end{array}$ & $\begin{array}{l}100 \\
20 \%\end{array}$ & $\begin{array}{l}350 \\
75 \%\end{array}$ & 18.0 & Rejected \\
\hline 5 & $\begin{array}{l}\text { Commitment are used to make the lesson clear and } \\
\text { simple }\end{array}$ & $\begin{array}{l}380 \\
76 \%\end{array}$ & $\begin{array}{l}100 \\
20 \%\end{array}$ & $\begin{array}{r}10 \\
2 \%\end{array}$ & $\begin{array}{l}10 \\
2 \%\end{array}$ & 33.0 & Accepted \\
\hline & Weighted mean & \multicolumn{6}{|c|}{26.0} \\
\hline
\end{tabular}


Moreover, in questionnaire item 5, a total number of 380 respondents strongly agreed that commitment is used to make the lesson clear and simple, 1 respondent strongly disagreed. This implies that commitment is used to make the lesson clear and simple if properly channel in entrepreneurial education, expected objectives can be achieved.

Research Question 2: What are the challenges facing the implementation of entrepreneurial skills in engineering program in Nigerian tertiary institutions?

In questionnaire item 1 , the respondents strongly agreed that resources are expensive, and some lecturers lack technical skills in discharging of their duty in teaching entrepreneurial subjects, while 10 respondents strongly disagree that resources are expensive and some lecturers lack technical skills in discharging of their duty representing the mean of 30.0. Also, in questionnaire item 2, 400 respondents strongly agreed that inadequate funding responsible for ability to assess self to start a job as an engineering student graduate and 30 respondents strongly disagree and the mean is 31.0

Furthermore, in questionnaire items no 3, 400 respondents strongly agreed that inability to write business plan hindered job opportunity; and 30 respondents disagreed. The mean for this questionnaire item is 31.0

Hypothesis: There is no significant difference between the perception of private and public tertiary institution lecturers on the challenges facing the implementation of entrepreneurial education program on engineering students in Nigerian tertiary institutions.

Table V shows that Public and Private Institution lecturers' perception has significant effect on the challenges facing the implementation of entrepreneurial education in Nigerian tertiary institutions $(\mathrm{t}=23.271, \mathrm{p}<0.05)$. The null hypothesis is not rejected.

TABLE IV: SHOWING RESPONDENTS THE CHALLENGES FACING THE IMPLEMENTATION OF ENTREPRENEURIAL SKILLS IN ENGINEERING PROGRAM IN

\begin{tabular}{|c|c|c|c|c|c|c|c|}
\hline $\mathrm{S} / \mathrm{N}$ & Items & SA & A & $\mathrm{D}$ & SD & Mean & Remark \\
\hline 1 & $\begin{array}{l}\text { Resources are expensive and some lecturers lack } \\
\text { technical skills in discharging of their duty. }\end{array}$ & $\begin{array}{l}450 \\
90 \%\end{array}$ & $\begin{array}{l}20 \\
4 \%\end{array}$ & $\begin{array}{l}20 \\
4 \%\end{array}$ & $\begin{array}{c}10 \\
2 \%\end{array}$ & 30.0 & Accepted \\
\hline 2 & $\begin{array}{l}\text { Inadequate funding responsible for ability to assess self } \\
\text { to start a job. }\end{array}$ & $\begin{array}{l}400 \\
80 \%\end{array}$ & $\begin{array}{c}50 \\
10 \%\end{array}$ & $\begin{array}{l}20 \\
4 \%\end{array}$ & $\begin{array}{l}30 \\
6 \%\end{array}$ & 31.0 & Accepted \\
\hline 3 & $\begin{array}{l}\text { Inability to write business plan hindered job } \\
\text { opportunity. }\end{array}$ & $\begin{array}{l}400 \\
80 \%\end{array}$ & $\begin{array}{c}50 \\
10 \% \\
\end{array}$ & $\begin{array}{l}20 \\
4 \%\end{array}$ & $\begin{array}{l}30 \\
6 \%\end{array}$ & 31.0 & Accepted \\
\hline & Weighted mean & \multicolumn{6}{|c|}{26.0} \\
\hline
\end{tabular}

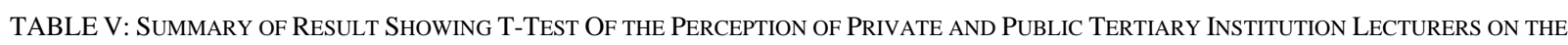
CHALLENGES FACING THE IMPLEMENTATION OF ENTREPRENEURIAL EDUCATION IN NIGERIAN TERTIARY INSTITUTIONS.

\begin{tabular}{cccccc}
\hline Variables & $\mathrm{N}$ & Mean & $\mathrm{SD}$ & $\mathrm{Df}$ & $\mathrm{T}$ \\
\hline Perception of Public Institution Lecturers & 103 & 31.88 & 6.08 & 130 & $23.271^{*}$ \\
Perception of Private Institution Lecturers & 29 & 22.87 & 5.23 & & \\
\hline
\end{tabular}

\section{DISCUSSION OF FINDINGS}

It's important to note that education is germane in acquiring entrepreneurial knowledge. Motivation from the stakeholders ought to play prominent role in arousing the interest of engineering students to become entrepreneurs of high quality is unfortunately seemly neglected. Obviously, the intention of the educational operators ought to be revolving round the creation of job with ease, but reverse is the case in Nigeria institution with gradual declining in skill acquisitions. The result is a half-baked workforce who are lacking in personal confidence and desire to achieve the objective of the employers. It is therefore become a distraction to the realization of young engineer's full potential

Now that the world system has changed overtime, entrepreneur should be in line with the global best practices in event operating within the sphere of education so as to prepare and empower the young entrepreneur with expected skills. In actual fact, entrepreneurial education seems neglected despite being agents of change in courses like engineering in Nigerian tertiary institutions. It is noticeable that inadequate remunerations pushed out some brilliant, skilled, and committed lecturers out of job left behind those with low technical skills which eventually hindered optimum potential.

It is understandable to note that entrepreneurial education has little or no impact on the training received in the Nigerian tertiary institution whereby majority of the graduates cannot put in business plan for an organization to follow.

\section{CONCLUSION AND RECOMMENDATIONS}

\section{A. Conclusion}

The study showed that entrepreneurship skills in our tertiary institutions are still at the infant stage. It has not been properly transmitted, acquired and rooted as a result of numerous challenges. The findings of the study revealed that many skills-gaps are left unattended to which slowing down the pace of academic progress in producing successful entrepreneurs. There are numerous missing skills in the practice that needs urgent attention such as risk taking, decision making, organizational skill, ICT compliant, ability to write business plan and innovation. However, the study showed that the following entrepreneurial skills can be acquired: self-confidence, leadership skill, achievement of intention, motivation, commitment, resourcefulness, reliable, hard work and optimism to better off rapid engineering development in Nigeria. Therefore, there is need to make sure that the courses related to skills development are taught both at undergraduate and graduate levels. This is to make sure that the students continue with the start-ups and discover better opportunities even after graduating.

Entrepreneurship education should be bedrock of engineering education. It is through effective entrepreneurship education that engineers will be able to 
adapt and react promptly to trends of doing things.

\section{B. Recommendations}

Based on the results of the findings of this research work, the following recommendations were made:

- $\quad$ The Federal Ministry of Education (FME) needs to start the issue of entrepreneurship education at the primary school level through the secondary schools to the university level, in order to close the low level skill acquisition gap. This will make our graduates to be selfreliant and adequately equipped for a start-up from the scratch.

- In order for the tertiary institutions to really fulfil its roles as a major catalyst for technological advancement and economic growth, there is need to bring into teaching, lecturers that are entrepreneurial inclined to develop study programs that enable students' creativity, initiative thinking and enhances original leadership thinking.

- Young entrepreneurs should be encouraged by creating an enabling environment through provision of quality education, starting capital with the necessary effective policies and legal support. Graduates should be encouraged and motivated through incentives from the government by introduction of soft loans facilities. Soft loans should be given to young graduates with necessary entrepreneurial skills as a way of encouragement with reduced interest rates.

\section{ACKNOWLEDGMENT}

The authors wish to appreciate the students and staff of Faculties of Engineering in EKSU, ABUAD, and FEDPOLY, Ado-Ekiti, Nigeria for their assistance in the field of study through questionnaires and inspection of their laboratories and entrepreneurial facilities.

\section{REFERENCES}

[1] M. Meresh, R. Harms, N. Kailer, and B. Wimeer, The Impact of Entrepreneurial Intention of Students in Sciences and Engineering versus Business Studies University Programs, Technological forecasting and social change, 104, 172-179, 2016.

[2] B. HjDin, B. H. Anuar and M. Usman, The Effectiveness of the Entrepreneurship Education Programs in Upgrading Entrepreneurial Skills among Public University Students, Procedia-social and Beha, 2016.

[3] N. Onuma, Entrepreneurship education in Nigerian tertiary institutions: a remedy to graduates unemployment, British journal of education, 4(5), 22-36, 2016.

[4] U. Bassey, Entrepreneurship education in Nigeria: Issues, challenges and strategies, Nigeria Journal of Bisiness Education, 4(1), 1-12, 2017.

[5] NBS, National Bureau of Statistics, Federal Republic of Nigeria, Abuja, 2020

[6] J. Ajayi, Graduate Unemployment and Criminality in Ado-Ekiti, International Journal of Business Management, 5(11), 61-77, 2015.

[7] J.U. Okorie and S.C.O.A. Ezeji, Elements of Guidance, Vocational and Carreer Education, Onitsha, Summer Education Publishers (Nig.) Limited, 1988.

[8] E. A. Amadi and S. E. Amakodi, Factors Influencing the implementation of entrepreneurship education in tertiary institutions in River state, International Journal of Innovative Social and science education research, 7(2),22-36, 2019.
[9] O. Longe, Graduate Unemployment in Nigeria: Causes, Consequences and Remediable Approaches, Journal of Contemporary Research, 7, 1$13,2017$.

[10] V. C. Onu and A. I. Ikeme, Entrepreneurship Education in Ensuring Change: Entrepreneurial Creativity for Entrepreneurship Education. Nsukka: Multi-Educational Services Trust, 2008.

[11] Deba, A. A. Deba, A. M. Khafa, A.M and A. Habibu, Enhancing Entrepreneurial Skills of Undergraduate Science, Vocational and Technical Education Students, Journal of Technical Education and Training, JTET, 6, (2), 2014.

[12] O. Etele, Entrepreneursim and Emerging Young Entrepreneurs, London: Withworth Books, 2007.

[13] E. Efiong, "Creativity and Global challenges." A paper presented at the International Conference on Education in the Information Age: Global Challenges and Enhancement Strategies, organized by the Faculty of Education, University of Nigeria, Nsukka, 2008.

[14] M. Jarrar, and H. Aris, "The Impacts of Entrepreneurship on Engineering Education" Proc.2016 Canadian Engineering Education Association (CEEA16) Conf. paper 098, Delhourse University: June 19-22, 1-6, 2016.

[15] P. Holzman, E Hertiluch and A. Puth, From Engineer to EntrepreneurEntrepreneurship Education for Engineering Students: The case of the Entrepreneurial Campus Villach, http://www.1-jep.eng, 2017.

[16] A. I. Mohammed, Y. B. Kamon and N. H. Wahid, The Need for Integrating Entrepreneurial Education and Training in Nigerian Technical Colleges: a preliminary study, International Journal of Recent Technology and Engineering, 8, 1-12, 2019.

[17] G. Celis, How intellectual movements among external and internal actors shape the college curriculum: The case of Entrepreneurship Education in Engineering" University of Michigan, Ann Arber, 2015.

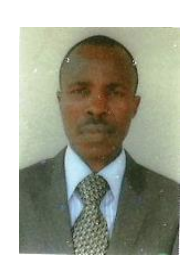

Bankole Adebanji received the B.Eng. degree in Electrical and Electronic Engineering in 1997 from the then Ondo State University, Ado-Ekiti, Ekiti State, Nigeria (now Ekiti State University, Ado-Ekiti), M. Tech. degree (Electronic and Electrical Engineering) and $\mathrm{Ph} . \mathrm{D}$ degree ( Power System Engineering and Machine) from Ladoke Akintola University of Technology (LAUTECH), Ogbomoso, Nigeria in 2010 and 2019 respectively.

His research interest is Renewable energy, Power system engineering, Hybrid, Small hydro and optimization. He is a registered COREN Engineer and a member of Nigerian Society of Engineers (MNSE).

$\mathrm{He}$ is currently lecturing in the Electrical and Electronic Engineering department of Ekiti State University, Ado-Ekiti, Nigeria.

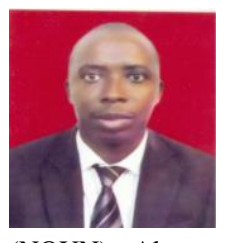

Bamidele Olusola Ogunlade received his master's and Ph.D degrees in Educational Technology from Ekiti State University, Ado - Ekiti in 2012 and 2015 respectively. He began as a lecturer $\mathrm{I}$ in Veritas University Abuja, Nigeria. $\mathrm{He}$ has served as Instructional/Tutorial Facilitator and Project Supervisor in National Open University of Nigeria (NOUN). Also, as external moderator to National Teachers Institute, Kaduna. He has served as supervisor to more than 15 master's recipients.

$\mathrm{He}$ is a member of Teachers Registration Council of Nigeria (TRCN), Educational Media and Technology Association of Nigeria (EMTAN), Association for Innovative Technology Integration in Education (AITIE) and Educational Researchers and Evaluators of Nigeria (ASSEREN).

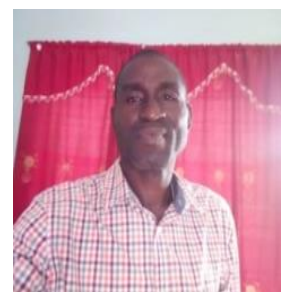

Kayode James Adebayo was born in Ado Ekiti, Nigeria in 1970. He bagged his B.Sc. (Ed.) degree in Mathematics Education from University of Ado Ekiti, Nigeria in 2006, M. Sc. and $\mathrm{Ph}$. D. in Mathematics from Ekiti State University, Ado Ekiti, Nigeria in 2011 and 2017 respectively.

His research interest has been in Optimization and Control Theory to which he has several publications in learned Journals. Presently, he lectures in Department of Mathematics, Ekiti State University, Ado Ekiti, Nigeria. 